DOI: http://doi.org/10.21698/simi.2018.fp37

\title{
USE OF REMOTE SENSING DATA IN INVESTIGATIONS OF ECOLOGICAL STATE OF WATER BODIES IN URBAN AREA OF KYIV CITY
}

Viktor Vyshnevskyi, Sergiy Shevchuk

Institute of Water Problems and Land Reclamation, 03022, Kyiv, 37 Vasylkivska, vishnev.v@gmail.com, sergey_shevchuk@ukr.net, Ukraine

\begin{abstract}
There are several hundreds of water bodies within the territory of Kyiv city. The biggest river is the Dnipro with many small urban rivers, lakes and ponds. Upstream of the city on the Dnipro river the Kyivske reservoir was constructed. Near the city another big river Desna flows into the Dnipro river. The ecological states of these water bodies differ greatly and it is worthy to note that the routine monitoring of these objects is irregular and limited. This resulted in the need of applying a new approach to the investigation of their ecological states. The investigation included field studies, using and processing of high-quality satelite images as well as analysing some hydrometeorological data. The field studies were carried simultaneously with the satellite survey. This enabled to get some dependences between measured and calculated data. Some patterns regarding water temperature, ice regime, water transparency, algal bloom as well as the ecological state of water objects in a whole were obtained. The Kyivske reservoir located upstream is an essential factor impacting on the Dnipro river and its gulfs. Another important factor which has a great effect on the ecological states of water objects is water exchange in them. In general, the ecological state of water bodies, connected with the Dnipro river is much better, than those without that connection.
\end{abstract}

Keywords: Dnipro river, ecological state, Kyiv, lakes, remote sensing

\section{Introduction}

There are many cities within the territories of which there are a large number of water bodies. Kyiv is considered to be one of them. Besides the Dnipro river there are several hundreds of water bodies in the territory of the city: small rivers, lakes and ponds. The length of the largest lakes and ponds can exceed $1 \mathrm{~km}$. In many cases the creation of lakes and increasing their sizes were caused by sand mining which was used for construction needs. That is the reason of prevailing location of the largest lakes on the left-bank flood plain of the Dnipro river (Figure 1).

The large number of water bodies does not enable to study them properly using routine monitoring. Under these conditions it is desirable to use remote sensing data. Relevant images cover all territory of the city that enables to compare ecological states of different water bodies simultaneously and repeatedly over the whole year. 


\section{INTERNATIONAL SYMPOSIUM "THE ENVIRONMENT AND THE INDUSTRY", SIMI 2018, PROCEEDINGS BOOK}

It is important to add that using the satellite images of medium spatial resolution is free of charge. Another important factor is obtaining of colored images, which are very illustrative.

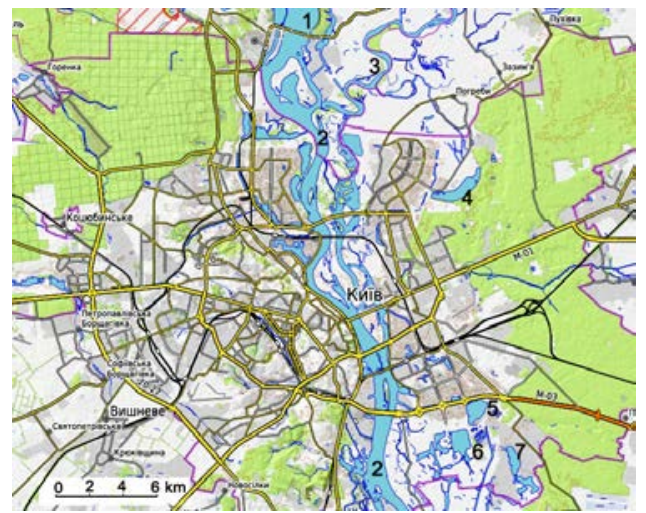

Figure 1. Kyiv and its main water bodies: 1 - the Kyivske reservoir, 2 - the Dnipro river, 3 - the Desna river, 4-6 - the largest lakes: respectively Almazne, Vurlitsa, Tjagle, Zaplavne

\section{Materials and methods}

The images obtained by the Landsat and Sentinel satellites were used for the investigation of Kyiv water bodies. These data are freely available on the site of the US Geological Survey [www.glovis.usgs.gov]. The spatial resolution for the most of spectral bands of Landsat satellite is $30 \mathrm{~m}$, of Sentinel satellite is $10 \mathrm{~m}$.

These data were processed using GIS-technologies. Water temperature and some other indexes such as NDTI, NDPI, NDVI etc., which are the ratio of spectral bands mainly in the visible part of spectrum, were calculated. Many digital colored images were obtained and analyzed afterwards.

Besides obtaining satellite images and their processing, the field study was carried out. Water temperature, water transparency and total suspended solids were measured.

The hydrometeorological data such as air temperature, wind direction and speed were collected from the data bases of Hydrometeorological Survey.

\section{Results and Discussion}

The carried out investigation enabled to specify some features of water temperature, ice regime and ecological state of the Dnipro River, its gulfs and other water bodies. Throughout the year their ecological states change greatly. The water temperature in the water bodies depends not only on season and air temperature, but on water exchange in them as well. The water temperature of the Dnipro River also depends on the distance from Kyivska hydroelectric power station, so in summer the coldest 


\section{INTERNATIONAL SYMPOSIUM "THE ENVIRONMENT AND THE INDUSTRY", SIMI 2018, PROCEEDINGS BOOK}

water is usually observed downstream of the Kyivska HPS. Water temperature rises as the distance from HPS and on the southern suburb of Kyiv city it can be $2{ }^{\circ} \mathrm{C}$ higher than it is near power station (Figure 2).

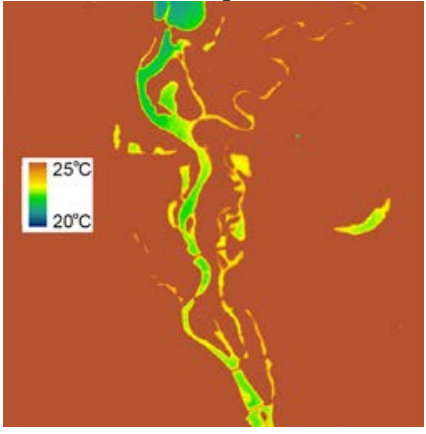

$a$

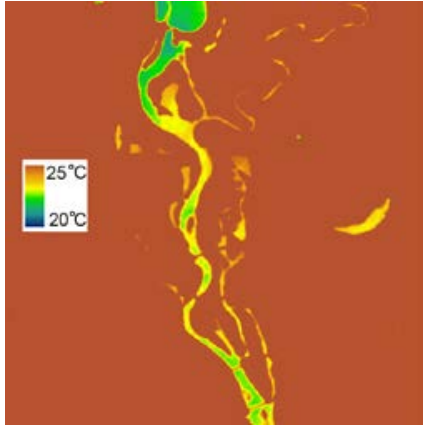

$b$

Figure 2. Surface water temperature: $a-13.07 .2016, b-29.07 .2016$

The temperature of water in the Desna River and lakes in summer is higher than the temperature of discharged water from Kyivska HPS. The irregular operation of the power station during twenty-four hours causes some differences in water temperature along the Dnipro River.

The vicinity of Kyivska HPS to the city has the essential impact on the ice cover in the river as well. As a rule even in cold winters a long ice-hole downstream the station can be observed. Another important factor influencing the ice regime of the Dnipro River is the operation of some industrial Kyiv enterprises, mainly thermal power plants (TPPs) near the Dnipro River. TPP-5 which uses water for cooling, is one of them. As a result of discharging heated water from that TPP an elongated icehole is usually formed near the right bank of the river. In the satellite images one can see the effect of one more enterprise - Bortnitska water treatment station, which is located on the south-eastern suburb of Kyiv city. The water discharge of this station exceeds 800 thousand cubic meters per day and the temperature of treated wastewater in winter is much higher than $0{ }^{\circ} \mathrm{C}$. As the result of this, ice cover downstream the water treatment station is absent (Figure 3). 


\section{INTERNATIONAL SYMPOSIUM "THE ENVIRONMENT AND THE INDUSTRY", SIMI 2018, PROCEEDINGS BOOK}

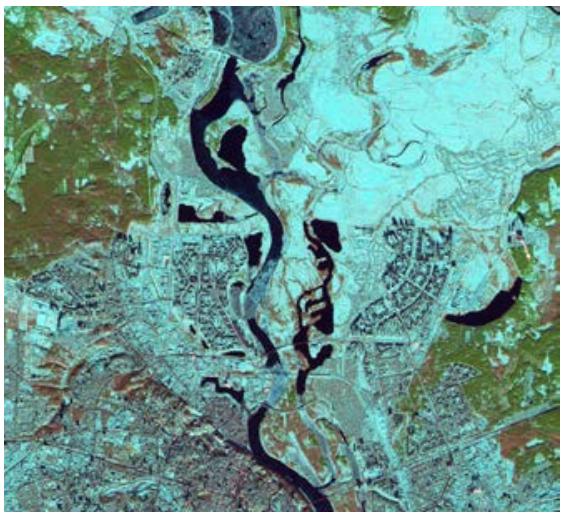

Figure 3. Ice cover in the Dnipro river on 07.12.2016

The important problem of the water bodies, located in Kyiv, is their ecological state. The specific phenomenon in them is algal bloom. During some last years which tended to be rather warm, the algal bloom was more intensive than in previous years. The peak of algal bloom is usually observed in the first part of August, while the water transparency at the same period is rather small: by the Secchi disk in the Dnipro River it can decrease to $1 \mathrm{~m}$ and in some lakes to $0.40 \mathrm{~m}$. In cold seasons the differences in water transparency in the river and lakes become less (Figure 4).
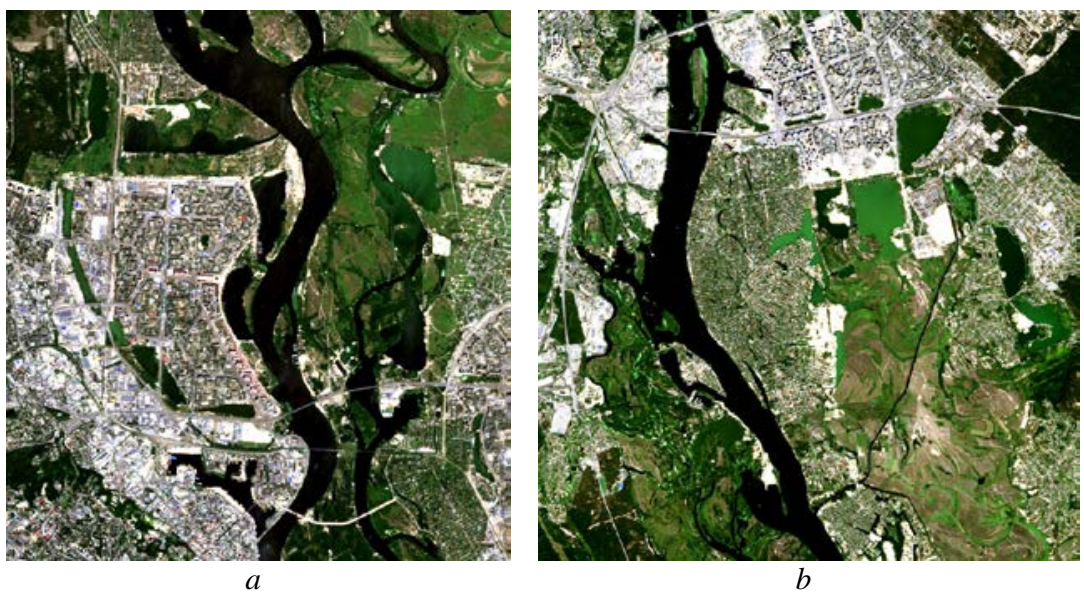

Figure 4. Algal bloom in the water bodies of Kyiv city on 17.08.2017:

$a-$ in the north part of city, $b$ - in the south-eastern part of city 


\section{INTERNATIONAL SYMPOSIUM "THE ENVIRONMENT AND THE INDUSTRY", SIMI 2018, PROCEEDINGS BOOK}

This figure shows the essential differences in water color of the Dnipro River and lakes. It is clearly seen the intensive algal bloom in Tjagle lake and some others located in the south-eastern part of Kyiv city.

Based on the obtained field and satellite data on algal bloom, water transparency and other characteristics some dependencies have been determined. There are correlation between water transparency measured with Secchi Disk and values of spectral bands B2, B3, B4 and B5 of Landsat 8 satellite. The close correlation is observed between water transparency and value of B3 spectral band that corresponds to green color. The correlation between water transparency and B4 spectral band that corresponds to red color is not so strong. The strongest correlation between water transparency and satellite data was obtained for the expression SD = (B4-B2) / B3 in summer conditions (Figure 5).

When using the data obtained in other seasons the above stated correlation is not so strong. It can be explained by the significant effect of algal bloom on the water transparency during summer (Vyshnevskyi \& Shevchuk 2016, 2018). The similar results were obtained by other authors in relevant studies (Allan et al 2007, Gholizadeh et al 2016, Shumakov 2008).

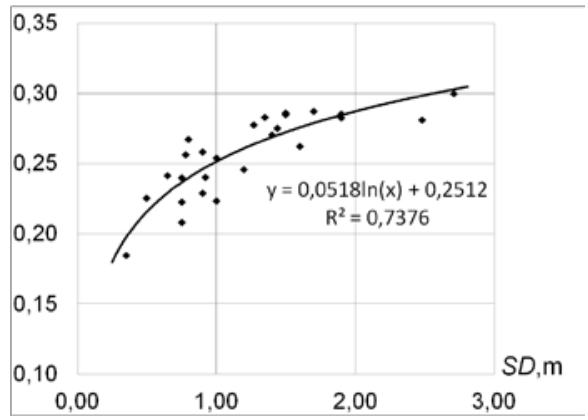

Figure 5. Correlation between water transparency by Secchi Disk and the values of (B2-B4) / B3 obtained for Kyiv water bodies during summer

NDTI index, which is the ratio of (B4-B3) / (B4+B3) was used for the evaluation of the ecological state of water bodies (fig. 6). The ratio of $((2 / 3) * \mathrm{~B} 5-$ $(1 / 3) * B 3) /((2 / 3 * B 5+(1 / 3) * B 3)$, proposed in paper (Burnis et al 2011), gives similar results. 

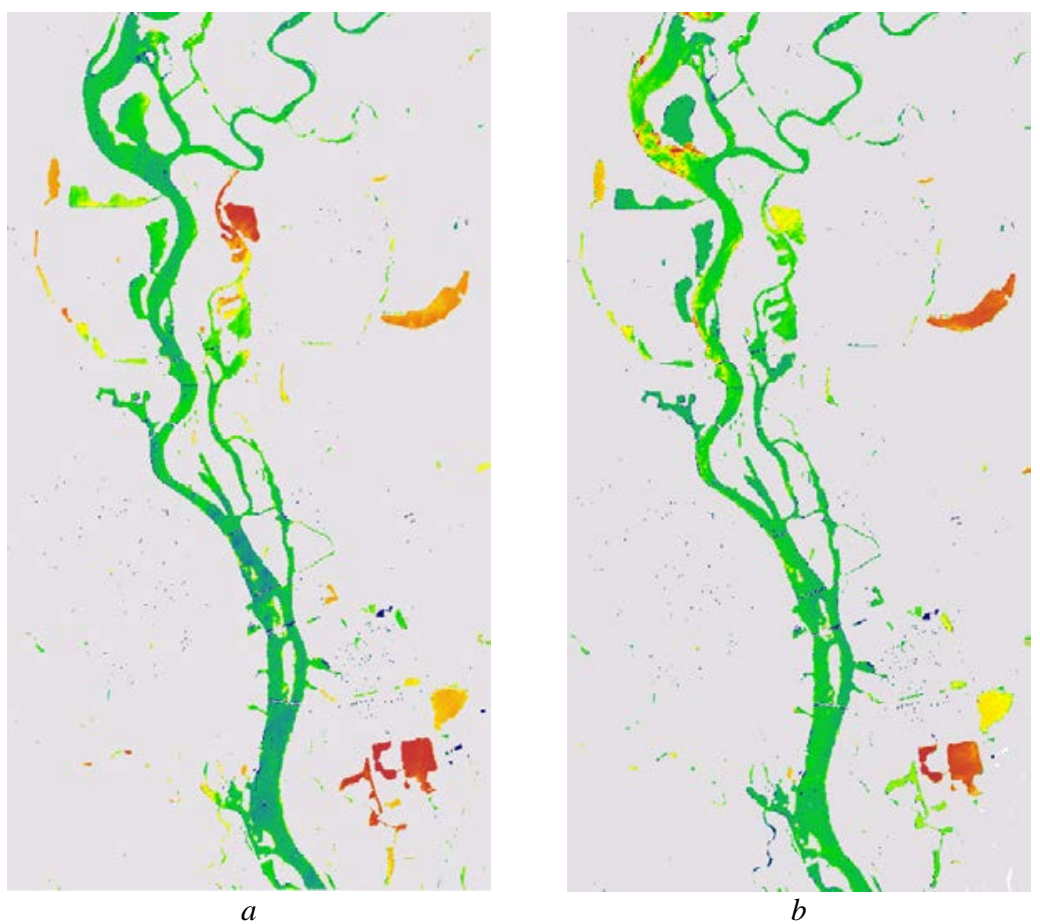

Figure 6. The images of water bodies located in Kyiv city calculated by NDTI index: $a-13.07 .2016, b-21.08 .2016$

The obtained figures show great differences in ecological states of the Dnipro River and lakes. Rather bad ecological states are usually observed in two largest Kyiv lakes: Almazne and Tjagle. There are some reasons for that. The poor ecological state of Almazne lake can be explained its specific shape. This lake is rather deep (up to $20 \mathrm{~m}$ ) and characterized by a rather small shallow area. That is way the spread of macrophytes is not essential. As the result of that nitrogen and phosphorus compounds are mainly absorbed by blue-green algae (Shevchuk et al 2017, Romanenko et al 2015).

\section{Conclusions}

The remote sensing and GIS-technologies are a useful toolkit, which enables to determine the ecological state of water bodies. During warm period water temperature in the Dnipro River near Kyiv city downstream of Kyivska HPS can have a rise by $2^{\circ} \mathrm{C}$. Kyivska HPS has a great effect on the ice cover near city as well. During winter time two enterprises, namely Kyivska TPP-5 and Bortnitska 


\section{INTERNATIONAL SYMPOSIUM "THE ENVIRONMENT AND THE INDUSTRY", SIMI 2018, PROCEEDINGS BOOK}

water treatment station influence the ice cover too. Great differences in ecological states of water bodies in Kyiv city can be observed. The most intensive algal bloom in water bodies is usually observed in the first part of August. At that time the water transparency in the Dnipro can drops up to $1 \mathrm{~m}$ and in lakes - up to $0.4 \mathrm{~m}$. In general the ecological state of the Dnipro River is considered to be much better than it is in the lakes with small water exchange. For the evaluation of the ecological state of water bodies NDTI and some other indices can be used.

\section{References}

Allan, M, Hicks, B, Brabyn, L 2007, 'Remote sensing of water quality in the Rotorua lakes’, CBER Contract Report, vol. 51, pp. 27.

Burnis, D, Bushuev, E, Voloshin, V 2011, 'Automatic technology of urban territory classification with use of data WORLDVIEW-2', Ecology and nature use, vol. 14, pp. 55-71.

Gholizadeh, M, Melesse, A, Reddi, L 2016, 'A comprehensive review on water quality parameters estimation using remote sensing techniques', Sensors, vol. 16, pp. 43.

Romanenko, O, Arsan, O, Kipnis, L, Sytnyk, Ju 2015, 'Ecological problems of Kyiv water objects and adjacent territory'. Naukova dumka, Kyiv, pp. 192.

Shevchuk, S, Kozutskyi, O, Vyshnevskyi, V 2017, 'Modern state of the Almazne lake and measure as to its improvements', Land reclamation and water management, vol. 105, pp. 39-45.

Shumakov FT 2008, 'Satellite monitoring of eutrophication of water recourses of Ukraine’, Municipal services of cities, vol. 79, pp. 217-231.

Vyshnevskyi, V \& Shevchuk, S 2018, 'The use of remote sensing data in the investigation of the water objects of Ukraine', Interpres LTD, Kyiv, pp. 116.

Vyshnevskyi, V \& Shevchuk, S 2016, 'The evaluation of the ecological state of the water objects of Kyiv with the remote sensing data', Ukrainian magazine of remote sensing, vol. 11 , pp. 4-9.

www.glovis.usgs.gov - site of the US Geological Survey 